Ann. rheum. Dis. (1960), 19, 163.

\title{
ON THE NATURE OF THE RHEUMATOID FACTOR*
}

\author{
BY \\ F. WÖHLER, W. MÜLLER, AND A. HOFMANN† \\ From the Internal Medicine Clinic of the University of Freiburg im Breisgau \\ (Director: Prof. L. Heilmeyer)
}

The researches initiated by Cecil, Nichols, and Stainsby (1931), Waaler (1940), and Rose, Ragan, Pearce, and Lipman (1949) on the agglutinating activity of serum from patients with rheumatoid arthritis led to the discovery of a serum factor, now regarded as characteristic of rheumatoid arthritis, and therefore designated "rheumatoid factor" (Pike, Sulkin, and Coggeshall, 1949; Svartz, 1956, 1959). This factor is important not only in differential diagnosis but also because it may take part in the pathogenesis of rheumatoid arthritis.

The rheumatoid factor has been located in the globulin fraction (Waaler, 1940), in Cohn's "Fraction III" (Heller, Kolodny, Lepow, Jacobson, Rivera, and Marks, 1955) and in the euglobulin fraction (Lamont-Havers, 1955; Svartz, Carlson, Schlossmann, and Ehrenberg, 1958; Svartz and Schlossmann, 1955); electrophoretically, it migrates with the gamma-globulin.

With the ultracentrifuge, the gamma-globulin fractions of normal serum can be shown to consist of two components, one having a sedimentation constant of 19 Svedberg units (19 S gamma-globulin) and a molecular weight of about 900,000 , the other having a sedimentation constant of 7 Svedberg units (7 S gamma-globulin) and a molecular weight of about 156,000 (Cohn, 1947; Müller-Eberhard, Kunkel, and Franklin, 1956; Müller-Eberhard, Franklin, and Kunkel, 1957; Pedersen, 1945; Wallenius, Trautman, Kunkel, and Franklin, 1957). The $19 \mathrm{~S}$ fraction amounts to only 5 per cent. of the total gamma-globulin. Müller-Eberhard (1959) and Schultze (1957) have demonstrated that the carbohydrate content of the $19 \mathrm{~S}$ component is four times higher than that of the $7 \mathrm{~S}$ component.

In the sera from rheumatoid patients, a com-

* Report to the IV European Congress of Rheumatology in Istanbul, September, 1959.

† With the support of the "Deutsche Forschungsgemeinschaft". ponent having a sedimentation constant of 22 Svedberg units has been detected (Fig. 1) (Franklin, Holman, Müller-Eberhard, and Kunkel, 1957; Franklin, Kunkel, Müller-Eberhard, and Holman, 1957; Franklin and Kunkel, 1957; Müller-Eberhard and others, 1956). Franklin and Müller-Eberhard and their co-workers have shown that this component is responsible for the positive agglutination reaction. They also demonstrated that the $22 \mathrm{~S}$ component represents a complex of $19 \mathrm{~S}$ and $7 \mathrm{~S}$ gamma-globulin in the ratio of $43: 57$ per cent.; and they conclude that there is one heavy for every six light molecules of gamma-globulin. Serological activity thus appears to be characteristic of the $19 \mathrm{~S}$ fraction.

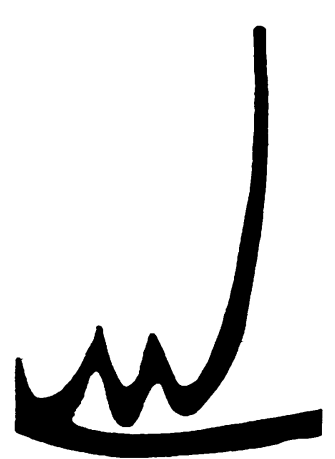

(a)

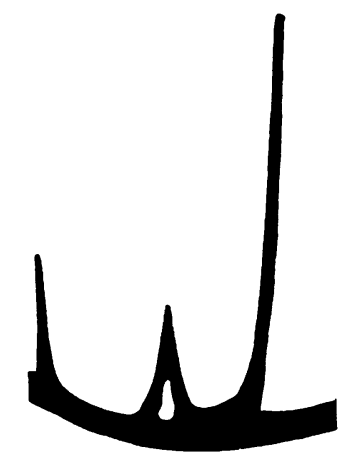

(b)
Fig. 1.-Comparison of ultracentrifugal patterns in normal and rheumatoid serum:

(a) Serum from a patient with rheumatoid arthritis, showing two components which sediment quickly, the physiological 19-S fraction and the pathological 22-S;

(b) Normal serum under same conditions (according to MüllerEberhard, Kunkel, and Franklin, 1957).

Studies utilizing zone electrophoresis, chromatography in cellulose columns and ultracentrifugation confirm that the rheumatoid factor is a macromolecular gamma-globulin of the $19 \mathrm{~S}$ type with 
a molecular weight of 900,000 (Franklin and others, 1957; Müller-Eberhard and others, 1956, 1957; Svartz, 1956, 1959; Svartz and others, 1955, 1958). According to Svartz (1959), it contains approximately 9 per cent. carbohydrate.

Apart from its serological reactivity the rheumatoid $19 \mathrm{~S}$ gamma-globulin reacts physically and chemically in the same way as normal $19 \mathrm{~S}$ gammaglobulin (Müller-Eberhard, 1959; Müller-Eberhard and others, 1957). Müller-Eberhard (1959) believes however, that a difference in molecular structure may account for the serologic reactivity.

It was therefore considered worth while to carry out a detailed chemical analysis of the rheumatoid factor.

\section{Method}

Pure rheumatoid factor was obtained by precipitation with gamma-globulin in the following way:

Serum from rheumatoid patients having high titres in erythrocyte and latex-fixation tests was mixed in $50 \mathrm{ml}$. aliquots with the same volume of a solution of gammaglobulin* and the mixture was added to borate buffer $(\mathrm{pH} 8.0)$ to give a concentration of 0.5 per cent. After 2 hours at room temperature and a further 46 hours at $4^{\circ} \mathrm{C}$., the resultant precipitate was separated by centrifugation at 17,000 r.p.m. for $20 \mathrm{~min}$. The precipitate was washed three times with distilled water and dried to a constant weight over concentrated sulphuric acid. To obtain a sufficient amount of precipitate, serum samples from five different patients were pooled.

The experiments of Müller-Eberhard have shown that the $7 \mathrm{~S}$ and $19 \mathrm{~S}$ fractions (Fig. 2) are in a ratio of $1: 1$ in a solution of the precipitate in the ultracentrifuge; aggregates with $35 \mathrm{~S}$ and $150 \mathrm{~S}$ were also observed

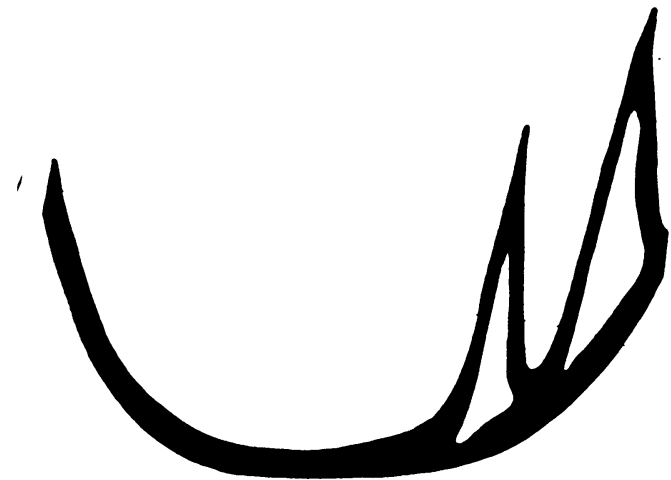

Fig. 2.-Analytical ultracentrifugal diagram of a precipitate solved in 5-M urea, which was gained by charging the serum of a rheumatoid patient with gamma globulin heated for a short period. The sedimentation coefficient of the quick component amounts to $19 \mathrm{~S}$ and that of the slow one to $7 \mathrm{~S}$.

* Behringwerke, Marburg. which derived from the $7 \mathrm{~S}$ gamma-globulin added for the precipitation. According to a personal communication from Müller-Eberhard, the gamma-globulin aggregates were found to amount to 50-70 per cent. of the total precipitate if the gamma-globulin was first heated. In the present experiments the gamma-globulin has not been heated. A solution of the precipitate in 5-M urea was repeatedly centrifuged at 20,000 r.p.m. for periods of up to 3 hours and the above mentioned aggregates were found to comprise 40 per cent. of the total precipitate. In repeated tests this component showed no serological activity. It was concluded that 70 per cent. of the precipitate consists of $7 \mathrm{~S}$ gamma-globulin, the remainder being $19 \mathrm{~S}$ gamma-globulin and corresponding to the rheumatoid factor. This ratio permits the two components to be estimated separately.

Colorimetric analyses of the carbohydrate were carried out. Hexoses were determined by the methods of Holzman, MacAllister, and Niemann (1947) and Winzler (1955); fucose by the method of Jacubeit, Brünger, and Knedel (1959); hexosamine by that of Dische and Borenfreund (1950); neuramine (sialic acid) $\uparrow$ by that of Schultze, Schmidtberger, and Haupt (1958); the polysaccharide was estimated by the tryptophane reaction (Shetlar, Foster, and Everett, 1948) and the total nitrogen by the method of Kjeldahl (Hallmann, 1950). The amino acids were determined by the method of Moore and Stein (1948) after protein hydrolysis (Zahn, 1954), and elution from a two-way paper chromatogram (Levy and Chung, 1953).

\section{Results}

Table I (opposite) shows the carbohydrate content of the rheumatoid factor, and normal $7 \mathrm{~S}$ and $19 \mathrm{~S}$ gamma-globulin.

The polysaccharide content of $7 \mathrm{~S}$ found by Müller-Eberhard and his co-workers (1956, 1957, 1959) is relatively low; the hexoses seem to be highest followed by hexosamine, fucose, and neuramine in that order. By comparison with $7 \mathrm{~S}$, the normal $19 \mathrm{~S}$ fraction presents a threefold increase in the polysaccharide content, a fourfold increase in hexoses, a twofold increase in fucose, and a sevenfold increase in neuramine.

The total carbohydrate content of the rheumatoid factor (10.78 per cent.) found by us is higher than the 9 per cent. reported by Svartz (1959). Our results for the carbohydrate components of the rheumatoid factor seem to correspond closely with those obtained by Müller-Eberhard for normal $19 \mathrm{~S}$ gamma-globulin.

Corresponding with the increased carbohydrate content, the total nitrogen content of the rheumatoid

$\dagger$ We are obliged to Dr. Brossmer of the Max Planck Institution for Medical Research, Sect.: Chemistry (Director: Dr. R. Kuhn, Heidelberg) for letting us have sialic acid with which to make calibration curves. 
TABLE I

CARBOHYDRATE CONTENT OF RHEUMATOID FACTOR (FRACTION $S_{20}=19$ S) COMPARED WITH NORMAL GAMMA GLOBULIN (FRACTIONS $S_{20}=7$ S AND $S_{20}=19$ S)

\begin{tabular}{|c|c|c|c|c|c|c|c|}
\hline \multirow{3}{*}{$\begin{array}{l}\text { Fraction .. } \\
\text { Authors and }\end{array}$} & \multirow{3}{*}{$\begin{array}{l}\cdots \\
\cdots\end{array}$} & \multirow{3}{*}{$\begin{array}{l}\cdots \\
\cdots \\
\cdots\end{array}$} & \multicolumn{4}{|c|}{ Normal Gamma Globulin } & \multirow{3}{*}{$\begin{array}{c}\begin{array}{c}\text { Rheumatoid } \\
\text { Factor }\end{array} \\
S_{20}=19 \mathrm{~S} \\
\begin{array}{c}\text { (Wöhler } \\
\text { and others, } \\
1960)\end{array}\end{array}$} \\
\hline & & & \multicolumn{2}{|c|}{$S_{20}=7 \mathrm{~s}$} & \multicolumn{2}{|c|}{$S_{20}=19 S$} & \\
\hline & & & $\begin{array}{l}\text { (Müller- } \\
\text { Eberhard, } \\
\text { 1959) }\end{array}$ & $\begin{array}{c}\text { (Wohler } \\
\text { and others, } \\
\text { 1960) }\end{array}$ & $\begin{array}{c}\text { (Müller- } \\
\text { Eberhard, } \\
\text { 1959) }\end{array}$ & (Schultze) & \\
\hline $\begin{array}{c}\text { Carbohydrate Content } \\
\text { (per cent.) }\end{array}$ & 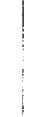 & $\begin{array}{l}\text { Hexose } . . \\
\text { Fucose } \\
\text { Hexosamine } \\
\text { Neuramine Acid } \\
\text { Polysaccharide }\end{array}$ & $\begin{array}{l}1 \cdot 22 \\
0 \cdot 29 \\
1 \cdot 14 \\
0 \cdot 22 \\
2 \cdot 58\end{array}$ & $\begin{array}{l}1 \cdot 23 \\
0 \cdot 3 \\
1 \cdot 2 \\
0 \cdot 25 \\
2 \cdot 7\end{array}$ & $\begin{array}{l}5 \cdot 2 \\
0 \cdot 62 \\
2 \cdot 9 \\
1 \cdot 7 \\
9 \cdot 8\end{array}$ & $\begin{array}{l}4 \cdot 16 \\
0 \cdot 46 \\
2 \cdot 4 \\
1 \cdot 81 \\
8 \cdot 83\end{array}$ & $\begin{array}{c}5 \cdot 13 \\
0 \cdot 85 \\
2 \cdot 9 \\
1 \cdot 84 \\
10 \cdot 78\end{array}$ \\
\hline
\end{tabular}

factor is smaller than the $7 \mathrm{~S}$ gamma-globulin, $14.7 \mathrm{~g}$. per cent. as against $16.03 \mathrm{~g}$. per cent. (Table II, overleaf).

When the two-way paper chromatography was applied after hydrolysis of protein, a large series of amino acids could be proved (Fig. 3).

The quantitative values of the amino acids in the rheumatoid factor and in $7 \mathrm{~S}$ gammaglobulin are shown in Table II. We used the amino acid composition of $7 \mathrm{~S}$ gamma-globulin (Brand, 1946; Brand, Kassell, and Saidel, 1944) for comparison because, according to Franklin and others (1957), Heimer (1959), and Heimer and Federico (1958), decomposition of the intermolecular S-S links of the rheumatoid factor is accompanied by a depolymerization into units of $7 \mathrm{~S}$ gamma-globulin; repolymerization may be prevented by adding monoiodine acetate (Isliker, 1958; Heimer, 1959; Heimer and Federico, 1958).

Glutamic acid comes first with about 13 per cent., followed by aspartic acid, valine, threonine, lysine, proline, leucine, serine, tyrosine, and so on. While in general the values seem to be somewhat lower in the rheumatoid factor, the values in the rheumatoid factor for cysteine and cystine are higher than in the $7 \mathrm{~S}$ gamma-globulin. The higher cystine value may be an expression of the increased S-S links which might be expected from the findings of Franklin and
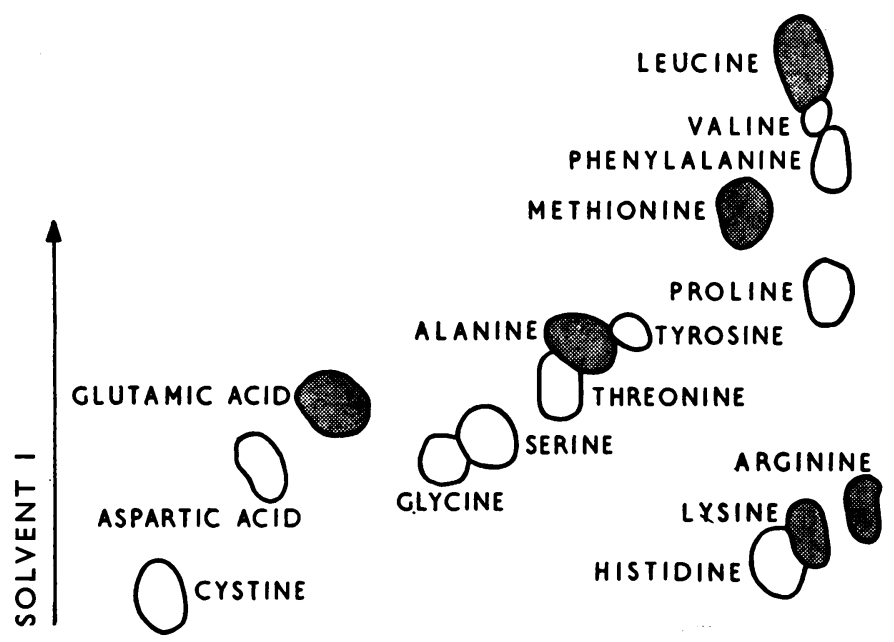

SOLVENT II

Fig. 3.-Two-way chromatogram of the rheumatoid factor.

Presentation of the amino acids with ninhydrine:

Solvent I: Isopropanolformic acid-glacial acetic acid-water, $500: 105: 105: 105$

Solvent II: Phenol-water mixture, 5 : 1. 
TABLE II

COMPOSITION OF AMINO ACIDS, AMOUNT OF NITROGEN, AND MOLECULAR WEIGHT OF RHEUMATOID FACTOR (S 19 FRACTION) COMPARED WITH NORMAL GAMMA GLOBULIN (S-7 FRACTION)

\begin{tabular}{|c|c|c|c|}
\hline \multicolumn{2}{|c|}{ Globulin Fraction } & $\begin{array}{l}\text { Normal Gamma } \\
\text { Globulin }\left(\mathrm{S}_{20}=7 \mathrm{~S}\right)\end{array}$ & $\begin{array}{l}\text { Rheumatoid Factor } \\
\qquad\left(S_{20}=19 S\right)\end{array}$ \\
\hline Molecul & ar Weight & $($ Cohn, 1957) & $\begin{array}{c}\text { (Müller-Eberhard, } \\
\text { 1959) }\end{array}$ \\
\hline Total N & $\begin{array}{l}\text { trogen } \\
\text { (per cent.) }\end{array}$ & ${ }_{16.03}$ & $\begin{array}{l}\text { (Wöhler and others, } \\
\text { 1960) } 14 \cdot 7\end{array}$ \\
\hline $\begin{array}{c}\text { Amino } \\
\text { Acids } \\
\text { (per } \\
\text { cent.) }\end{array}$ & $\begin{array}{l}\text { Glycine } \\
\text { Alanine } \\
\text { Valine } \\
\text { Leucine } \\
\text { Isoleucine } \\
\text { Proline } \\
\text { Phenylalanine } \\
\text { Cysteine } \\
\text { Cystine } \\
\text { Methionine } \\
\text { Tryptophan } \\
\text { Arginine } \\
\text { Histidine } \\
\text { Lysine } \\
\text { Aspartic acid } \\
\text { Glutamic acid } \\
\text { Serine } \\
\text { Threonine } \\
\text { Tyrosine }\end{array}$ & $\begin{array}{c}\text { (Brand, 1946) } \\
4 \cdot 2 \\
2 \cdot 2 \\
9 \cdot 7 \\
9 \cdot 3 \\
2 \cdot 7 \\
8 \cdot 1 \\
4 \cdot 6 \\
0 \cdot 7 \\
2 \cdot 37 \\
1 \cdot 06 \\
2 \cdot 86 \\
4 \cdot 8 \\
2 \cdot 5 \\
8 \cdot 1 \\
8 \cdot 8 \\
11 \cdot 8 \\
11 \cdot 4 \\
8 \cdot 4 \\
6.75\end{array}$ & $\begin{array}{c}\text { (Wöhler and others, } \\
\text { 1960) } \\
3 \cdot 6 \\
2 \cdot 0 \\
8 \cdot 2 \\
7 \cdot 3 \\
2 \cdot 3 \\
7 \cdot 6 \\
4 \cdot 5 \\
0 \cdot 99 \\
3 \cdot 4 \\
1 \cdot 1 \\
2 \cdot 7 \\
4 \cdot 2 \\
3 \cdot 0 \\
7 \cdot 7 \\
9 \cdot 6 \\
13 \cdot 1 \\
7 \cdot 3 \\
8 \cdot 2 \\
7 \cdot 0\end{array}$ \\
\hline
\end{tabular}

others (1957) regarding depolymerization of the rheumatoid factor. Although the amino acid percentage composition of the rheumatoid factor and normal $7 \mathrm{~S}$ gamma-globulin appear to be similar, one cannot be certain that the quantitative values are identical.

The present results have enabled the carbohydrate content and the amino acid composition of the rheumatoid factor to be established. Since its carbohydrate content resembles that of the normal $19 \mathrm{~S}$ gamma-globulin fraction and its amino acids correspond with $7 \mathrm{~S}$ gamma-globulin, this protein and $19 \mathrm{~S}$ may be closely related. Which physicochemical correlate the serological activity is based on cannot be decided. Examination of the active end-groups might help to elucidate this problem.

\section{Summary}

Chemical analyses have been made on the rheumatoid factor isolated by precipitation with gammaglobulin. The carbohydrate content of the rheumatoid factor is similar to that of normal $19 \mathrm{~S}$ gamma-globulin: hexose $5 \cdot 13$ per cent., fucose 0.85 per cent., hexosamine 2.9 per cent., and neuramine 1.84 per cent. The percentage amino acid composition of the rheumatoid factor was similar to that of normal $7 \mathrm{~S}$ gamma globulin.

\section{REFERENCES}

Bohm, P., St. Dauber, and Baumeister, L. (1954). Klin. Wschr., 32, 289.

Brand, E. (1946). Ann. N.Y. Acad. Sci., 47, 187.

, Kassell, B., and Saidel, L. J. (1944). J. clin. Invest., 23, 437.

Cecil, R. L., Nicholls, E. E., and Stainsby, W. J. (1931). Amer. J. med. Sci., 181, 12.

Cohn, E. J. (1947). "History of Plasma Fractionation". New York Dische, Z., and Borenfreund, E. (1950). J. biol. Chem., 184, 517.

Franklin, E. C., Holman, H. R., Müller-Eberhard, H. J., and Kunkel, H. G. (1957). J. exp. Med., 105, 425 - and Kunkel, H. G. (1957). J. Immunol., 78, 11.

-, Müller-Eberhard, H. J., and Holman, H. R. (1957) Ann. rheum. Dis., 16, 315.

Hallmann. L. (1950). "Klinische Chemie und Mikroskopie," 6th ed. Thieme, Stuttgart.

Heimer. R. (1959). Arthr. and Rheum., 2, 266.

and Federico, O. M. (1958). Clin. chim. Acta, 3, 496

Heller, G Kolodny M. H. Lepow, I. H. Jacobson A. S. Rivera, M. E., and Marks, G. H. (1955). J. Immunol., 74, 340.

Holzman, G., MacAllister, R. V., and Niemann, C. (1947). J. biol. Chem., 171, 27.

Isliker, H. (1958). Helvet. med. acta, 25, 41.

Jacubeit, M., Brünger, P., and Knedel, M. (1959). Klin. Wschr., 37,460 .

(1955), Proc. Soc. exp. Biol. (N.Y.), 88, 35.

Levy, A. L., and Chung, D. (1953). Anal. Chem., 25, 396.

Moore, S., and Stein, W. H. (1948). J. biol. Chem., 178, 367

Müller, W., and Haftstein, F. (1959). Z. klin. Med., 156, 154

Müller-Eberhard, H. J. (1959). Dtsch. med. Wschr., 84, 719.

-, Franklin, E. C., and Kunkel, H. G. (1957). Verh. dtsch. Ges. inn. Med., 63, 642 .

-, Kunkel, H. G., and Franklin, E. C. (1956). Proc. Soc. exp. Biol. (N.Y.) 93, 146.

Pedersen, K. O. (1945). "Ultracentrifugal Studies on Serum and Serum Fractions." Almquist and Wiksells, Uppsala.

Pike, R. M., Sulkin, S. E., and Coggeshall, H. C. (1949). J. Immunol., 63, 441.

Rose, H. M., Ragan, C., Pearce, E., and Lipman, M. O. (1948). Proc. Soc. exp. Biol. (N.Y.), 68, 1.

Schultze, H. E. (1957). Scand. J. clin. Lab. Invest., 10, Suppl. 31, 135. Schmidtberger, R., and Haupt, H. (1958). Biochem. Z., $329,490$.

Shetlar, M. R., Foster, J. V., and Everett, M. R. (1948). Proc. Soc. exp. Biol. (N.Y.), 67, 125.

Svartz, N. (1956). Rheumatism, 12, 76

- (1959). Triangle, 4, 23.

Carlson, L. A., Schlossmann, K., and Ehrenberg, A. (1958) Acta med. scand., $160,87$.

- and Schlossmann, K. (1955). Ann. rheum. Dis., 14, 191

Waaler, E. (1940). Acta path. microbiol. scand., 17, 172.

Wallenius, G., Trautman, R., Kunkel, H. G., and Franklin, E. C. (1957), J. biol. Chem., 225, 253.

Winzler, R. J. (1955). Meth. Biochem. Anal., 2, 290.

Zahn, H. (1954). Textilpraxis, p. 124.

\section{Sur la nature du facteur rhumatismal}

\section{RÉSUMÉ}

Le facteur rhumatismal, isolé par précipitation avec la globuline gamma, fut soumis à l'analyse chimique. Le contenu en hydrates de carbone du facteur rhumatismal est similaire à celui de la globuline gamma $19 \mathrm{~S}$ normale: hexose $5,13 \%$, fucose $0,85 \%$, hexosamine $2,9 \%$ et neuramine $1,84 \%$. Le pourcentage des aminoacides dans le facteur rhumatismal fut similaire à celui de la globuline gamma $7 \mathrm{~S}$ normale.

\section{Sobre la naturaleza del factor reumatoide}

\section{SUMARIO}

El factor reumatoide, aislado por precipitación con la globulina gama, fué sometido al análisis químico. El contenido en hidratos de carbono del factor reumatoide es similar al de la globulina gama $19 \mathrm{~S}$ normal: hexosa $5,13 \%$, fucosa $0,85 \%$, hexosamina $2,9 \%$ y neuramina $1,84 \%$. La proporción de los amino-ácidos en el factor reumatoide fué similar a la en la globulina gama $7 \mathrm{~S}$ normal. 